\title{
Parenteral nutrition at the end of life
}

Karine Blom Kjerulf

Kreftsykepleier

Oslo universitetssykehus, Ullevål

Ellen Karine Grov

Professor

Institutt for sykepleie og helsefremmende arbeid, Fakultet for helsevitenskap, Oslomet storbyuniversitetet

End of life Cancer Parenteral nutrition Healthcare personnel Qualitative study

Sykepleien Forskning 202015 (82609) (e-82609)

DOI: 10.4220/Sykepleienf.2020.82609

\section{Summary}

Background: Weight loss and undernourishment are common secondary diagnoses for cancer patients in the palliative phase. This often means that patients are treated with parenteral nutrition. Research shows that there is no clear benefit from treatment with parenteral nutrition when cancer patients approach the end of life. Whether to continue or stop the treatment can therefore represent a challenge for healthcare personnel, patients and their relatives. Few qualitative studies have investigated how healthcare personnel experience their work with parenteral nutrition at the end of life.

Objective: The study's objective was to describe the challenges that healthcare personnel in hospitals experience in connection with administering parenteral nutrition to cancer patients at the end of life.

Method: Qualitative study involving individual interviews with six registered nurses and two oncologists who work with cancer patients at two hospitals in eastern Norway. We made use of systematic text condensation to analyse the data. 
Results: The analysis revealed one overarching theme: making decisions about whether to stop parenteral nutrition at the end of life requires extensive experience-based knowledge and interaction between doctors and registered nurses. Two main categories emerged: 1) dialogue, reflection and providing information about life and death to patients and their relatives 2) assessment perspectives and knowing the patient.

Conclusion: The participants described the importance of communicating information about end-of-life parenteral nutrition at an early stage of the disease. The study suggests a need for clear routines and guidelines for parenteral nutrition, although the participants describe experience-based knowledge and interdisciplinary collaboration as the most important factors in assessing the patient's condition.

A Norwegian study showed that 66 per cent of cancer patients on a palliative care ward, suffered from undernourishment (1). Food and drink are essential parts of life, and cancer patients who are nearing the end of life, will often have a waning interest in food and drink (2).

When patients are unable to absorb sufficient nutrition orally or enterally, parenteral nutrition can be appropriate (3). Parenteral nutrition is a medical treatment that involves administering intravenous nutrition straight into the vein (4).

Indications to start parenteral nutrition include expected shortening of life due to undernourishment, expected improvement to the quality of life, or that this is in accordance with the wishes of patients and their relatives (35).

\section{Definition of the end of life}

In a clinical context, healthcare personnel often define the end of life in different ways. It is far from easy to pinpoint the start of this phase. The Norwegian Association for Palliative Care and the Norwegian Association for Palliative Medicine define the end of life in this way: When the remaining life expectancy is likely, on balance, to be severely limited, often a matter of weeks or days. (6)

\section{Earlier research and guidelines}

According to several studies, guidelines and handbooks, patients should not receive parenteral nutrition in the last two or three months of life, because the clinical benefit is doubtful (3, 7-9). Ethical guidelines recommend stopping the treatment if the risk and the side effects involved outweigh the benefits (10). 
Nevertheless, several studies show that treatment with parenteral nutrition commences and continues at the end of life $(11,12)$. One study found that the use of parenteral nutrition increased considerably when death was approaching and the use of chemotherapy was reduced, and 16 per cent of cancer patients received artificial nutrition in their last week of life (11).

Another study reported that artificial nutrition had been considered, planned or commenced in 50 per cent of hospitalised in-patients at the end of life (12). Parenteral nutrition in this phase may aggravate the patient's condition, involving increased pain, infections, heavy breathing and oedema $(8,13,14)$.

Clinical assessments are therefore essential for deciding when to start or stop treatment at the end of life. Because the guidelines and several studies do not recommend parenteral nutrition at the end of life, the patient's functions and prognosis must be rigorously considered in order to evaluate whether it is probable that the patient will benefit from the treatment.

The benefits and disadvantages of treatment must be assessed on an ongoing basis, mental pressures must be taken into account, and it is necessary to identify what patients and their relatives expect from the treatment (4). A systematic literature search identified only a single study that had made use of a qualitative methodology in order to cast a light on these themes, thereby enabling the production of in-depth knowledge.

That study dealt with the experiences of nurses who provided palliative care to patients receiving parenteral nutrition in their own home (15).

\section{The objective of the study}

The objective of our study was to describe the challenges faced by healthcare personnel in association with administering parenteral nutrition to hospitalised cancer patients at the end of life.

\section{Method}




\section{Design}

The study had a descriptive and exploratory qualitative design and took a phenomenological approach. Phenomenology directs attention to subjective experiences $(16,17)$. The phenomenological perspective represents a philosophy which considers the experiences of human beings to be validated knowledge (17).

\section{Recruitment and sample}

Registered nurses (RNs) and doctors were recruited via heads of departments and sections who forwarded the invitation to participate to potential candidates. Inclusion criteria for study participation were: RNs and doctors with a minimum of five years' experience plus a minimum of three years' experience of working on a cancer ward.

The informants were RNs from three oncology inpatient wards and oncologists from two hospitals in eastern Norway. The sample consisted of six RNs, all female, and two oncologists, both male.

The informants worked with cancer patients at all stages of the disease. On average, the RNs had twelve years' experience of working in an oncology department. All except one had specialised in cancer nursing. The oncologists had more than 20 years' professional experience.

\section{Data collection}

We collected the data between October and December 2017. All interviews were conducted at the respective hospital premises during the informants' working hours. The data were collected by using a thematic interview guide with the following content: experiences of parenteral nutrition at the end of life, ethical dilemmas, disagreement among healthcare personnel, information and guidelines.

We recorded the interviews on tape and they were transcribed verbatim by the first author. One of the interviews lasted 15 minutes. The duration of the other interviews was $40-50$ minutes.

\section{Data analysis}

We analysed the data material by using systematic text condensation in accordance with Malterud's description of the phenomenological approach based on her interpretation of Giorgi. 
The analysis was conducted in four stages: 1) overall impression, 2) meaning units, 3) condensation, and 4) synthesis (17). The text material was entered in an Excel spreadsheet and we used colour coding to systemise thematic areas. Table 1 shows an extract from this analysis.

Table 1. Extracts from the analysis

\begin{tabular}{|c|c|}
\hline $\begin{array}{l}\text { Meaning units from } \\
\text { the theme of 'Patients } \\
\text { and relatives despair'. } \\
\text { These were grouped } \\
\text { in the category of 'Di- } \\
\text { alogue, reflection and } \\
\text { providing information } \\
\text { about life and death } \\
\text { to patients and their } \\
\text { relatives' }\end{array}$ & $\begin{array}{l}\text { A 'When the patient is so ill that he's unable to eat, I often find that patients and their relatives fight hard for them } \\
\text { to receive parenteral nutrition, because that's the last thing that keeps them alive.' } \\
\text { B 'I do think that's a challenging part of palliative care, because you feel that you take away some of their hope.' } \\
\text { C'They may well be hoping that they will get better, but I have never seen a single example of patients getting better, } \\
\text { not a single one.' } \\
\text { D 'And in a way, you then deprive the patients of their hope that life will continue.' } \\
\text { E 'If you take it away, you take away the chance of life.' } \\
\text { F 'It's a difficult decision for doctors because it seems as if doctors think that if we discontinue, then we take away } \\
\text { the patient's chance of life.' } \\
\text { G 'If you stop PE nutrition, it tends to be associated with stopping other types of active treatment.' } \\
\text { A 'It's something that relatives tend to have very strong opinions about .... And I have found that they fight hard for it.' } \\
\text { B 'Gradually it becomes kind of an expectation. That since they have been receiving it for so long, they should continue } \\
\text { to receive it.' } \\
\text { C'When it comes to nutrition right up until the moment of death, it is the relatives who wield the power: are you } \\
\text { really going to let my mother starve to death? [...] That's because the explanations they receive aren't thorough } \\
\text { enough, they understand if it's explained to them.' } \\
\text { D 'Most people want treatment, and particularly the relatives. Sometimes the patient may say they want to end it, } \\
\text { but relatives want to continue, virtually all the time.' } \\
\text { E'I've never heard relatives asking for the treatment to stop, for after all, it's food that keeps people alive, so it } \\
\text { represents hope in a way.' } \\
\text { F'I can understand that patients choose PE if they are hanging on to a sort of life line or something that gives you } \\
\text { a hope of living for a little longer.' } \\
\text { G 'There are a lot of strong-willed relatives around, and they can be very opinionated when it comes to the right } \\
\text { thing to do.' } \\
\text { H 'The relatives can be insistent. They don't always understand. They think we're starving the patient.' }\end{array}$ \\
\hline $\begin{array}{l}\text { Step 1: } \\
\text { Preliminary themes }\end{array}$ & relatives despair \\
\hline $\begin{array}{l}\text { Step 2: } \\
\text { From themes to codes }\end{array}$ & $\begin{array}{l}\text { Depriving patients and relatives of their hope } \\
\text { Stopping parenteral nutrition - the last thing that keeps them alive }\end{array}$ \\
\hline $\begin{array}{l}\text { Step 3: } \\
\text { Sub-groups: }\end{array}$ & Patients and relatives associate nutrition with life and hope \\
\hline $\begin{array}{l}\text { From code to } \\
\text { condensed meaning }\end{array}$ & $\begin{array}{l}\text { 'I feel that by stopping parenteral nutrition, we deprive patients and relatives of their hope.' 'I feel that patients and } \\
\text { relatives associate nutrition with hope and life.' 'I find that patients and their relatives fight hard for them to receive } \\
\text { parenteral nutrition, because that's the last thing that keeps them alive.' 'I find that all relatives want the patient to } \\
\text { receive parenteral nutrition, and they don't want the treatment to be stopped.' }\end{array}$ \\
\hline 'Golden quotes' & $\begin{array}{l}\text { A 'When the patient is so ill that he is unable to eat, I often find that patients and their relatives fight hard for them } \\
\text { to receive parenteral nutrition, because that's the last thing that keeps them alive.' } \\
\mathrm{H} \text { 'The relatives can be insistent. They don't always understand. They think we are starving the patient.' }\end{array}$ \\
\hline $\begin{array}{l}\text { Step 4: } \\
\text { Synthesising, } \\
\text { recontextualisation } \\
\text { of categories }\end{array}$ & $\begin{array}{l}\text { The informants expressed a sense of depriving patients and relatives of their hope by stopping parenteral nutrition. } \\
\text { The hope of living a little longer. In the words of Nurse }(A) \text { : 'When the patient is so ill that he is unable to eat, I often } \\
\text { find that patients and their relatives fight hard for them to receive parenteral nutrition, because that's the last thing } \\
\text { that keeps them alive.' } \\
\text { All informants reported that relatives wanted the patient to receive parenteral nutrition. Relatives also tended } \\
\text { to voice strong objections to ending the treatment. In the words of Doctor }(\mathrm{H}) \text { : 'The relatives can be insistent. } \\
\text { They don't always understand. They think we are starving the patient.' }\end{array}$ \\
\hline
\end{tabular}

\section{Ethical considerations}

The study was approved by the Norwegian Centre for Research Data (NSD), project number 55281. Participants received spoken and written information before they gave their consent to taking part in the study.

The data material was de-identified and stored, in accordance with the provisions of the Norwegian Personal Data Act, on an encrypted memory chip separate from the consent forms (18). 


\section{Results}

The analysis brought out one overarching theme: making decisions about parenteral nutrition at the end of life requires extensive experience-based knowledge and interaction between doctors and registered nurses. Two categories and sub-categories are presented in Table 2.

Table 2. Categories and sub-categories

\begin{tabular}{|l|l|l|l|l|l|}
\hline Categories & \multicolumn{2}{|l|}{$\begin{array}{l}\text { Dialogue, reflection and providing } \\
\text { information about life and death to patients } \\
\text { and their relatives }\end{array}$} & $\begin{array}{l}\text { The assessment perspective } \\
\text { and knowing the patient }\end{array}$ \\
\hline Sub-categories & $\begin{array}{l}\text { Patients and relatives } \\
\text { associate nutrition } \\
\text { with life and hope }\end{array}$ & $\begin{array}{l}\text { Could we have } \\
\text { planted this seed } \\
\text { earlier? }\end{array}$ & $\begin{array}{l}\text { Doctors and RNs assess } \\
\text { the situation differently } \\
\text { based on their fields of } \\
\text { competence }\end{array}$ & $\begin{array}{l}\text { Difficult } \\
\text { to predict } \\
\text { the future }\end{array}$ & $\begin{array}{l}\text { Patients } \\
\text { receive } \\
\text { treatment } \\
\text { for too long }\end{array}$ \\
\hline
\end{tabular}

\section{Dialogue, reflection and providing information about life and death to patients and their relatives}

This category involved a description of the healthcare personnel's reflections and dialogue with patients and their relatives.

Patients and relatives associate nutrition with life and hope

The informants felt that by not commencing or by discontinuing parenteral nutrition, they deprived patients and their relatives of the hope that life would go on for as long as possible. This is how Nurse A explains it: 'When the patient is so ill that he's unable to eat, I often find that patients and their relatives fight hard for them to receive parenteral nutrition, because that's the last thing that keeps them alive.'

All the informants reported that relatives wanted patients to receive parenteral nutrition. Also, relatives often objected vehemently to stopping the treatment because they tended to associate the discontinuation of parenteral nutrition with the patient starving and dying.

In the words of Doctor H: 'The relatives can be insistent. They don't always understand. They think we're starving the patient.' 


\section{Could we have planted this seed earlier?}

According to the informants, patients and their relatives generally received very little information before treatment with parenteral nutrition, and only rarely were plans drawn up before commencing.

Clear treatment objectives and evaluations were seldom discussed, nor was information provided about when to stop the treatment. On the contrary, several informants commented that patients and their relatives never asked for information, and that they were often appreciative of the patient receiving parenteral nutrition.

The findings suggest that no standard patient information material about parenteral nutrition had been developed, and the information that was provided, tended to be generalised and with a focus on side effects: 'It's not as if we have lots of standard information about it, like we have for chemotherapy or various other treatments. So when it comes to nutrition, it tends to be just: if you feel unwell or queasy, we'll slow it down.' Nurse D

The informants described that decisions about stopping treatment with parenteral nutrition often appeared to come out of the blue for patients and their relatives: 'We need to start planting that seed a little earlier than what is currently the case. I often think it comes far too late. It's a little sudden, because we're not very good at keeping them informed as we go along.' Nurse A

\section{三 «The relatives wanted to know why parenteral nutrition was discontinued.»}

The doctors believed that a clear plan with well-defined treatment objectives and expectations should be discussed before commencing. The doctors and RNs all emphasised the importance of repeatedly providing patients and their relatives with in-depth information, and that a robust knowledge base would make it easier to accept the decision to stop the treatment with parenteral nutrition.

The relatives wanted to know why parenteral nutrition was discontinued, and this type of information must be clear, since many relatives believe that the patient will starve if parenteral nutrition is stopped. 
Both the RNs and the doctors were less than familiar with the guidelines for parenteral nutrition. Nevertheless, several participants said that parenteral nutrition should not be administered in the two or three last months of life. Several informants wanted clear guidelines, and pointed out that such guidelines would be particularly important when arguing the case for stopping treatment.

The need for guidelines is illustrated by Doctor H: 'It's important to issue guidelines for the whole department to follow, so that it's not left to chance depending on who is on duty, or whose shift it is. That's probably the important thing to focus on in this context. We have limited knowledge, so research is essential.'

\section{The assessment perspective and knowing the patient}

This category involved different assessments of the patient's prognosis, and challenges associated with continuing treatment with parenteral nutrition for too long.

\section{Doctors and RNs assess the situation differently based on their fields of competence}

The doctors and RNs reported that they frequently discussed treatment with parenteral nutrition at the end of life and that there was often disagreements. According to several RNs, it could be difficult to argue against the doctors for the treatment to be stopped.

Some of the RNs also felt that their professional assessments were not taken seriously. This is how Nurse D put it: 'As a nurse, you never have the last say. The medical arguments carry more weight than what the nurses have to say about the patient's quality of life.'

The RNs explained that they were better able to tell exactly how poorly a patient actually is, because they keep a closer eye on patients round the clock. Also, they had acquired experience-based competence, which enabled them to identify with greater ease the signs of life coming to an end: 'It takes many years to develop the clinical gaze which enables you to see that a patient is dying. That's really quite an important gaze.' Nurse C

\section{'The doctors explained that they respected the RNs' assessments because they spend more time with the patients.»}


The doctors explained that they respected the RNs' assessments because they spend more time with the patients. Also, doctors could mistakenly believe that patients were feeling better than they really were, because patients tend to put on a brave face when they are seen by a doctor.

In the words of Doctor G: 'Sometimes it is the nurses, who observe the patient round the clock, who point out that this is an extremely poorly patient who for some reason manages to put on a brave face every time they are seen by a doctor, so that the doctors form a different impression of them. And trying to find the right balance in all this, is not easy.'

Several informants mentioned that inter-disciplinary cooperation was important in order to assess and discuss patients whenever opinions differed about their condition.

\section{Difficult to predict the future}

The findings showed that it is not always easy to gauge when patients approach the end of life. Whenever there was doubt about a prognosis, this was often caused by inadequate knowledge of the patient: 'Often, we don't know the patients well enough. When they aren't with us for very long, we're unable to form the full picture, and in those situations it is much easier to continue than to stop.' Nurse F

It emerged that the patients could be stable for a good while before a sudden turn for the worse. The findings also show that identifying the point when a patient has only a few months left to live, could be difficult. In the words of Doctor G: 'If we knew when they all had two or three months left to live, it would have been simple, but that's just not how it is.'

\section{Patients receive treatment for too long}

All the RNs had experienced that patients had been receiving parenteral nutrition for too long, and that it was stopped only days or hours before death. Several of them talked about incidents when parenteral nutrition was still being administered when the patient died.

One of the RNs explained that she felt it was meaningless and unethical: 'I don't think it's dignified. For when you get to the end of life, the body can no longer absorb nutrition, it's the other way around, the bodily response is pain.' Nurse C 
Although one of the doctors said that there was no point in administering parenteral nutrition to someone in a terminal phase, several of the RNs had experienced that parenteral nutrition was continued in the last months of life.

The RNs identified a number of side effects of the treatment, such as nausea, oedema, pain and heavy breathing. They also pointed out that hooking up the medical equipment affected the patient's quality of life and freedom of movement.

Table 3 illustrates the step-wise data analysis procedure, with descriptions.

Table 3. The four-step analysis leading to an overarching theme*

\begin{tabular}{|c|c|c|c|c|}
\hline $\begin{array}{l}\text { Step } 1 \\
\text { Preliminary themes }\end{array}$ & $\begin{array}{l}\text { Step } 2 \\
\text { Codes }\end{array}$ & $\begin{array}{l}\text { Step } 3 \\
\text { Sub-groups }\end{array}$ & $\begin{array}{l}\text { Step } 4 \\
\text { Category }\end{array}$ & $\begin{array}{l}\text { Overarching } \\
\text { theme }\end{array}$ \\
\hline $\begin{array}{l}\text { Patients } \\
\text { and relatives de- } \\
\text { spair }\end{array}$ & $\begin{array}{l}\text { Deprive patients and relatives } \\
\text { of hope } \\
\text { Stopping parenteral nutrition - the } \\
\text { last thing that keeps them alive }\end{array}$ & $\begin{array}{l}\text { Patients and relatives } \\
\text { associate nutrition with } \\
\text { life and hope }\end{array}$ & \multirow{2}{*}{$\begin{array}{l}\text { Dialogue, } \\
\text { reflection } \\
\text { and providing } \\
\text { information } \\
\text { about life and } \\
\text { death to patients } \\
\text { and their } \\
\text { relatives }\end{array}$} & \multirow{5}{*}{$\begin{array}{l}\text { Making } \\
\text { decisions } \\
\text { about whether } \\
\text { to stop parenteral } \\
\text { nutrition at } \\
\text { the end of life } \\
\text { requires extensive } \\
\text { experience-based } \\
\text { knowledge and } \\
\text { interaction } \\
\text { between doctors } \\
\text { and nurses }\end{array}$} \\
\hline $\begin{array}{l}\text { Communication } \\
\text { and information } \\
\text { involving patients } \\
\text { and relatives }\end{array}$ & $\begin{array}{l}\text { The information comes too late } \\
\text { Patients and relatives never ask } \\
\text { for information } \\
\text { Denied an informed choice } \\
\text { No standard information available }\end{array}$ & $\begin{array}{l}\text { Could we have } \\
\text { planted this seed } \\
\text { earlier? }\end{array}$ & & \\
\hline $\begin{array}{l}\text { Inter-disciplinary } \\
\text { cooperation }\end{array}$ & $\begin{array}{l}\text { The doctor needs the nurses' } \\
\text { assessments } \\
\text { Different opinions on how poorly } \\
\text { the patients are }\end{array}$ & $\begin{array}{l}\text { Doctors and nurses } \\
\text { assess the situation } \\
\text { differently based on their } \\
\text { fields of competence }\end{array}$ & \multirow{3}{*}{$\begin{array}{l}\text { The assessment } \\
\text { perspective and } \\
\text { knowing the } \\
\text { patient }\end{array}$} & \\
\hline Prognose & $\begin{array}{l}\text { Who can tell when the patient has } \\
\text { two or three months left to live? } \\
\text { No clear guidance on what to do } \\
\text { when life is nearing the end }\end{array}$ & $\begin{array}{l}\text { The assessment } \\
\text { perspective and } \\
\text { knowing the } \\
\text { patient }\end{array}$ & & \\
\hline $\begin{array}{l}\text { The difficult } \\
\text { challenges in } \\
\text { clinical } \\
\text { practice }\end{array}$ & $\begin{array}{l}\text { What should the end of life } \\
\text { be all about? } \\
\text { There is no point in administering } \\
\text { parenteral nutrition at the end of life }\end{array}$ & $\begin{array}{l}\text { Patients receive } \\
\text { treatment for } \\
\text { too long }\end{array}$ & & \\
\hline
\end{tabular}

* Overarching theme: Making decisions about whether to stop parenteral nutrition at the end of life requires extensive experience-based knowledge and interaction between doctors and nurses.

\section{Discussion}

This study shows that making decisions about stopping parenteral nutrition at the end of life requires extensive experience-based knowledge and interaction between doctors and registered nurses. The results show the complexity of the dilemmas faced by healthcare personnel. 
Whenever the question of whether to stop parenteral nutrition arises, the patient's best interest is best determined through a combination of nursing assessments, medical knowledge, and information communicated to patients and relatives that explains how parenteral nutrition starts and stops.

\section{Decisions based on involvement, guidelines and experience-based knowledge}

Parenteral nutrition is a medical treatment that often stirs strong emotions in patients and relatives. If we do not eat, we die. Relatives are rarely familiar with the converse - that when we are dying, we do not eat (19).

The informants found it difficult to stop treatment with parenteral nutrition because relatives associated the treatment with maintaining life and believed that the patient would starve if the treatment was discontinued. Similar findings have been described in several earlier studies $(8,13$, $20,21)$.

A lack of knowledge can cause patients and relatives to entertain unrealistic expectations of the treatment with parenteral nutrition. Many patients and relatives know very little about the treatment and its side effects, and about the natural dying process (7).

\section{$\equiv$ ¿The informants found it difficult to stop treatment with parenteral nutrition.»}

Without the necessary information, patients and relatives will have inadequate knowledge of side effects and problems that can arise from treatment with parenteral nutrition at the end of life, and about what happens during the natural dying process.

The informants explained that the question of stopping parenteral nutrition often came out of the blue for patients and relatives, because they had insufficient knowledge. Plans were rarely drawn up at an early stage of the end of life, before treatment with parenteral nutrition commenced, as suggested by Sævareid et al. on a general basis (22). 
Similar findings have been described in earlier studies, revealing that patients and relatives receive little information that might help their decision-making $(20,23)$. Information can lead to a more well-considered choice. Danis et al. maintain that providing the necessary information may result in more frequent decisions by patients and relatives to abstain from treatment with parenteral nutrition (8).

Health literacy is a concept that reflects the level of knowledge about an aspect of health. It has been argued that a personcentred approach depends on the health literacy of patients and relatives, as is a health plan that secures patient autonomy (24).

The level of health literacy should be assessed prior to the conversation, to ensure that the exchange of information is adapted to the literacy level of patients and their relatives. Ethical reflection is applied through the dissemination of information, and it must be ascertained that the information content has been understood.

Guidelines, earlier studies $(3,9,19,25)$ and handbooks issued by the Norwegian Directorate of Health (7) also highlight the importance of informing patients and relatives about treatment choices and the effects and side effects of treatment with parenteral nutrition.

The findings of this study suggest that no standard information has been prepared on parenteral nutrition, and that healthcare personnel are unfamiliar with the guidelines. One of the informant doctors mentioned that it would be useful to have access to guidelines for the whole department to follow. International guidelines often provide general advice, which make them difficult to apply in practice (15).

The study results show that patients receive parenteral nutrition during the end-of-life phase, despite a recognition that this is not advisable. According to Dy, the use of parenteral nutrition could have been halved if the guidelines had been followed (25).

National guidelines are essential in order to optimise health literacy and enable an informed choice. The guidelines must build on knowledge-based practice and encompass evidence from research, experience and knowledge of the patient's wishes and needs (26). 


\section{The ethical imperative to act in the patient's best interest}

The informant nurses considered that patients were treated with parenteral nutrition for too long, and several of them had experienced that patients died while receiving parenteral nutrition. It is difficult to decide whether patients die from a disease or undernourishment.

It is unethical to allow a patient to die from undernourishment, but it is also unethical to allow a patient to suffer unnecessarily and to prolong their suffering by administering parenteral nutrition (20).

The fact that the informants had seen patients receive parenteral nutrition at the point of death, and that several side effects of the treatment were revealed, touch on two important principles in medical ethics: nonmaleficence (do no harm) and beneficence (do good).

It is not always easy to do the right thing and act in the patient's best interest if you are uncertain when the patient enters the end-of-life phase. The informants were often unsure about the patient's prognosis and saw it as a challenge to assess exactly when patients have two or three months left to live. Similar findings have been described in a number of studies $(9,13,23)$.

\section{$\equiv \ll$ It is not always easy to do the right thing and act in the patient's best interest if you are uncertain when the patient enters the end-of-life phase.»}

It is difficult to decide when to stop parenteral nutrition, and uncertainty about the patient's prognosis restricts our ethical imperative to act. Instead, the healthcare personnel await the course of events until they observe the signs that life is nearing the end.

It has been documented that doctors can be too optimistic when they consider the patient's prognosis (11). This supports our study's finding that doctors see patients putting on a brave face during their visits. Doctors and RNs can therefore arrive at different conclusions about the patient's prognosis. 
It is important that RNs ask questions about the patient's best interest, discuss this with colleagues and report to the doctor if in their opinion the treatment contributes to prolonging the patient's suffering. There are several useful indicators, such as tools that help assess the patient's prognosis and remaining life expectancy (27), and in this study, reference is made to the 'clinical gaze' of experiencebased knowledge.

Nursing assessments and action competence support the decision-making processes that should and must be the remit of an inter-disciplinary team. Palliative care is, by definition, an inter-disciplinary approach (28). Any decision about whether to continue or discontinue parenteral nutrition should be based on an inter-disciplinary assessment of the patient's condition $(9,11,13,14,29)$.

\section{The study's strengths and weaknesses}

In qualitative studies, a low number of informants is sufficient if the interviews produce rich data. In this study, both doctors and registered nurses are represented, and the number of informants in each group reflects the relationship between the number of practicing doctors and practicing RNs. This is a strength of the study.

It is also a strength that the doctors and most of the RNs had specialised in the field of oncology and could draw on extensive experience of palliation. By including the perspectives of both doctors and RNs, we accessed the professions that specifically work with parenteral nutrition at the end of life. This is considered a strength.

One of the study's weaknesses is the fact that the oncologist sample included men only, while all the RNs were women. The oncologists who took part in the study, undertook most of their work in the out-patients clinic, which may have been a restricting factor since out-patients tend to be in better health than patients in inpatient wards. Our findings might therefore have been different had we obtained our data from healthcare personnel who work solely with patients in the palliative phase.

\section{Conclusion}


Considering whether to discontinue parenteral nutrition should be based on inter-disciplinary cooperation and the competence of healthcare personnel, particularly their experience-based knowledge that enables them to recognise the symptoms and signs that are prevalent at the end of life. Healthcare personnel are looking for tools that can help them assess the patient's prognosis and enable them to tell with greater certainty when the patient is nearing the end of life.

Clinical guidelines on parenteral nutrition should be drawn up based on knowledge-based practice. This must include information about when to stop parenteral nutrition. There is a need for more knowledge about the level of information that patients and relatives require, and about how to map the health literacy of patients and relatives so as to optimise their decisions about parenteral nutrition.

\section{References}

1. Thoresen L, Fjeldstad I, Krogstad K, Kaasa S, Falkmer UG. Nutritional status of patients with advanced cancer: the value of using the subjective global assessment of nutritional status as a screening tool. Palliative Medicine. Jan. 2002;16:33-42.

2. Brenne AT, Dalene R. Symptomlindring av den døende pasienten. In: Kaasa S, Loge JH, eds. Palliasjon: Nordisk lærebok. 3rd ed. Oslo: Gyldendal Akademisk; 2016. pp. 638-51.

3. Bozzetti F, Arends J, Lundholm K, Micklewright A, Zurcher G, Muscaritoli M. ESPEN guidelines on parenteral nutrition: non-surgical oncology. Clin Nutr. Aug. 2009;28(4):445-54.

4. Good P, Richard R, Syrmis W, Jenkins-Marsh, S, Stephens J. Medically assisted nutrition for adult palliative care patients. Review. Cochrane Database of Systematic Reviews. Apr. 2014;4:1-16.

5. Bye A, Balstad TR. Ernæring - generelle prinsipper. In: Kaasa S, Loge JH, eds. Palliasjon: Nordisk lærebok. 3rd ed. Oslo: Gyldendal Akademisk; 2016. pp. 232-43. 
6. Norsk Palliativ Forening, Norsk forening for palliativ medisin. Begreper med tilknytning til palliasjon. Oslo: Den norske legeforening; 2016. Available at:

https://www.legeforeningen.no/foreningsledd/spesial/norskforening-for-palliativ-medisin/aktuelt/begreper-medtilknytning-til-palliasjon/ (downloaded 20.10.2020).

7. Helsedirektoratet. Veileder for beslutningsprosesser ved begrensning av livsforlengende behandling. Oslo: Helsedirektoratet; 2013. IS-209. Available at: https://helsedirektoratet.no/retningslinjer/beslutningsprosess er-ved-begrensning-av-livsforlengende-behandling (downloaded 08.01.2018).

8. Danis M, Arnold RM, Savarese DMF. Stopping artificial nutrition and hydration at the end of life. Literature review. UpToDate. May 2018:1-21. Available at: https:/www.uptodate.com/contents/stopping-nutrition-andhydration-at-the-end-of-life (downloaded 20.10.2020).

9. Orrevall Y. Nutritional support at the end of life. Nutrition. Apr. 2015;31:615-6.

10. Druml C, Ballmer PE, Druml W, Oehmichen F, Shenkin A, Singer $\mathrm{P}$, et al. ESPEN guideline on ethical aspects of artificial nutrition and hydration. Clin Nutr. Jun. 2016;35(3):545-56.

11. Kempf E, Tournigand C, Rochigneux P, Aubry R, Morin L. Discrepancies in the use of chemotherapy and artificial nutrition near the end of life for hospitalized patients with metastatic gastric or esophageal cancer. A countrywide, register-based study. European Journal of Cancer. Jul. 2017;79:31-40.

12. Desmedt MS, Kethulle YL, Deveugele M I, Keirse EA, Paulus DJ, Menten JJ, et al. Palliative inpatients in general hospital: a one day observational study in Belgium. BMC Palliative Care. Mar. 2011;10(2):1-8.

13. Bailey FA, Harman SM, Bruera E, Arnold RM, Savarese DMF. Palliative care: the last hours and days of life.

UpToDate. Jul. 2018:1-49.

14. Seres D, Parsons PE, Lipman TO. Nutrition support in critically ill patients: parenteral nutrition. Literature review. UpToDate. Jul. 2018:1-8. 
15. Holmdahl S, Sävenstedt S, Imoni R. Parenteral nutrition in home-based palliative care: Swedish district nurses experiences. Journal of Caring Sciences. Mar. 2014;28(1)8996.

16. Thornquist E. Vitenskapsfilosofi og vitenskapsteori: for helsefag. Bergen: Fagbokforlaget; 2012.

17. Malterud K. Kvalitative metoder i medisinsk forskning: en innføring. 4th ed. Oslo: Universitetsforlaget; 2017.

18. Christoffersen L, Johannessen A, Tufte PA, Utne I. Forskningsmetode for sykepleierutdanningene. Oslo: Abstrakt forlag; 2015.

19. Vathorst SVD. Artificial nutrition at the end of life: ethical issues. Best Practice \& Research Clinical Gastroenterology. Apr. 2014;28:247-53.

20. Lembeck ME, Pameijer CR, Westcott AM. The role of intravenous fluids and enteral and parenteral nutrition in patients with life-limiting illness. Med Clin N Am. Sep. 2016;100;1131-41.

21. Bükki J, Unterpaul T, Nübling G, Jox R.J, Lorenzl S. Decision making at the end of life-cancer patients' and their caregivers' views on artificial nutrition and hydration. Support Care Cancer. Dec. 2014;22:3287-99.

22. Sævareid TJL, Lillemoen L, Thoresen L, Førde R, Gjeberg E, Pedersen R. Implementing advance care planning in nursing homes - study protocol of a cluster-randomized clinical trial. BMC Geriatrics. Aug. 2018;18(180):1-12.

23. Dev R, Dalal, S, Bruera E. Is there a role for parenteral nutrition or hydration at the end of life? Curr Opin Support Palliat Care. Sep. 2012;6:365-70.

24. Hernandez L, French M, Parker R. Roundtable on health literacy: issues and impact. Stud Health Technol Inform. 2017;240:169-85.

25. Dy SM. Enteral and parenteral nutrition in terminally ill cancer patients: a review of the literature. American Journal of Hospice \& Palliative Medicine. Oct.-Nov. 2006;5:369-377. 
26. Helsebiblioteket. Kunnskapsbasert praksis. Oslo:

Helsebiblioteket; 2017. Available at:

https://www.helsebiblioteket.no/kunnskapsbasert-praksis

(downloaded 27.04.2018).

27. Feliu J, Jiménez-Gordo AM, Madero R, Rodriguez-

Aizcorbe JR, Espinosa E, Castro J, et al. Development and validation of a prognostic nomogram for terminally ill cancer patients. J Natl Cancer Inst. Oct. 2011;103:1613-20.

28. Helsedirektoratet. Nasjonalt handlingsprogram for palliasjon i kreftomsorgen utgitt av Helsedirektoratet. Oslo: Helsedirektoratet; 2015. IS-2285. Available at: http://helsedirektoratet.no/retningslinjer/nasjonalthandlingsprogram-med-retningslinjer-for-palliasjon-ikreftomsorgen (downloaded 30.01.2018).

29. Helsedirektoratet. Nasjonale faglige råd for lindrende behandling i livets sluttfase. Oslo: Helsedirektoratet; 2018. Available at: https://helsedirektoratet.no/palliasjon/nasjonalefaglige-rad-for-lindrende-behandling-i-livets-sluttfase (downloaded 05.10.2018). 